\title{
An Experiment Of Student Understanding Of Accruals Versus Cash Flows
}

Jose Eduardo Miranda-Lopez, (E-mail: jose.eduardo.miranda@itesm.mx), Tecnologico de Monterrey Campus Guadalajara, Mexico Linda M. Nichols, (E-mail: Linda.nichols@ttu.edu), Texas Tech University

\begin{abstract}
The concepts of both accrual accounting and cash basis accounting need to be thoroughly understood by accounting graduates as they enter the workplace. In making decisions, both managers and investors often may need to make adjustments from one basis to the other. But do students really understand these concepts? This study uses an experimental approach to determine if students in both the U.S. and Mexico understand the association between accrual and cash flow numbers in the area of depreciation. The results reveal that the majority of student participants in both countries do not understand the relationship between depreciation and cash flows. This suggests that the way depreciation is taught in intermediate accounting may need to be approached differently in order for students to understand the nature of depreciation and its effect on earnings and cash flows.
\end{abstract}

\section{INTRODUCTION}

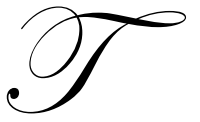

he role of both accrual income and cash flows in assessing business performance and position has been long recognized. Prior research in the United States (U.S.) has reflected the importance of accounting earnings to U.S. statement users (Bowen et al., 1987; Dechow 1994; Biddle et al., 1997; Moehrle et al., 2001). Research in other countries has shown that cash flows are more important to decision makers than earnings (Bartov et al., 2001). Given the importance of both accrual earnings and cash flows on a global basis, do we as educators do an adequate job in teaching the differences between accrual and cash-based income?

This study uses an experimental approach to determine if students understand the association between accrual and cash flow in the area of depreciation. Further, to test if this difference varies outside of the U.S., the experiment is conducted in both the U.S. and Mexico. Prior research has shown that in Mexico, accruals decrease the value relevance of earnings to decision makers relative to information on cash flows (Hung 2001). Because cash flows are relied on more by decision makers in Mexico, we expect the students in Mexico to reflect a higher level of understanding regarding the cash flow effect of depreciation.

The participants are undergraduate and graduate students at a university in the southwest U.S. and at a university in Mexico. The participants are presented with complete financial statements for a hypothetical business and are asked to decide if they would keep the business for the next two years or if they would sell it depending on their analysis. The results reveal that the majority of participants in both countries failed to adjust earnings for depreciation in trying to project cash flows.

This study contributes to the field of accounting education globally. Participants in both countries in this study did not adjust earnings to reflect that depreciation is a non-cash expense in projecting cash flows. This suggests that the way depreciation is taught in intermediate accounting may need to be approached differently in order for students to understand the nature of depreciation and its effect on earnings and cash flows.

The remainder of the paper proceeds as follows. Section II discusses related prior research, Section III describes the research design, Section IV discusses the results of the experiment, and Section V draws conclusions and summarizes the paper's contribution. 


\section{BACKGROUND AND PRIOR RESEARCH}

The importance of both earnings and cash flows has been documented in the accounting literature for decades. An early study by Beaver and Dukes (1972) found that earnings are more associated with stock returns than are cash flows. Following the release of SFAS No. 95, "Statement of cash flows," a study by Bowen et al. (1986) found that the cash flow statement provides incremental information content relative to earnings. More recently, Dechow (1994) tested whether earnings had a stronger association with stock returns relative to net cash flows or cash from operations over short measurement intervals. Dechow found that accruals outperform cash flows in the short run, because earnings are more strongly associated with stock returns than are realized cash flows. However, she found that cash flow numbers seem to improve relative to earnings if the period is extended.

In the international arena, several studies have attempted to determine if the superior explanatory power of earnings over cash flows generally found in the U.S. could be generalized to other countries. In order to do this, these studies tested the value relevance of earnings and cash flows across countries with different legal traditions. Bartov et al. (2001) tested whether earnings or cash flows provided more information for equity valuation within the United States, the United Kingdom, Canada, Germany and Japan. They found that earnings numbers had greater explanatory power for stock returns than did cash flow measures in the three Anglo-Saxon countries. Hung (2001) examined the relationship between the use of accruals and the value relevance of accounting measures across countries, using the investor protection laws as a benchmark. Her results indicate that the use of accrual accounting (versus cash flows) decreases the value relevance of accounting performance measures in the financial statements in countries with weak stockholder protection.

Capital markets research has been somewhat limited in Mexico due to the lack of extensive databases. Swanson et al. (2003) studied the value relevance of financial information after the 1994 devaluation of the peso in Mexico. They found that earnings were not value relevant in the period following the devaluation.

We introduce accounting education research in Mexico, providing some of the first evidence of similarities or differences between students in the U.S. and Mexico. Research supports the importance of both earnings and cash flow figures, but indicates that cash flow information seems to be utilized more in Mexico. Therefore, we would expect that students in Mexico may demonstrate a higher level of understanding of cash flows than do students in the U.S.

\section{RESEARCH DESIGN}

The research question addressed in this study is if students are able to adjust accrual earnings figures for depreciation in projecting cash flows. We also want to know if a difference is displayed in this ability between students in the U.S. and Mexico. Our hypothesis and expectation is therefore:

Ho: $\quad$ Mexican (U.S.) students will be more (less) often be able to correctly adjust earnings figures for depreciation in projecting cash flows.

The student participants in both countries were assigned the role of a person who just received a tomato farm as a gift from an uncle. The gift was conditioned so that the recipient could keep the farm and the proceeds for two years after which the farm would be transferred to a third party, or the recipient could sell the farm to a neighbor now and keep the proceeds. The recipients received financial statements for the farm for the previous two years.

The variable of home country is manipulated by having experimental sessions in both the U.S. and Mexico. The participants in this study were junior and senior level undergraduate accounting majors and MBA students. The students were from a large university in the southwestern U.S., and from a large university in Mexico. As motivation for participants, a drawing for $\$ 100$ or the equivalent amount in Mexican Pesos was held at the end of each experimental session, in which all participants who made the correct decision were entered. 
The experimental procedure consisted of six steps:

1. The participants answered five questions from a practice admission test to the MBA program at the university in Mexico. This provided a control measure to test for differences in academic ability.

2. The participants read the rules, instructions, and the case.

3. The participants received the financial statements for the previous two periods and the amount offered to buy the farm.

4. Participants answered questions about the statements, which were used to assess their understanding of the statements and basic accounting knowledge.

5. The participants calculated the value of the farm and decided whether to keep or sell the farm.

6. Exit questions focused on how they reached their decision, and provided demographic information.

In total, 213 students participated in the study including 103 students in the U.S. and 110 students in Mexico. Six participants in the U.S. and two participants in Mexico were eliminated because they were not natives of those respective countries. In addition, seven U.S. participants and four Mexican participants were eliminated because they used an accounting measure other than earnings or cash flows in their analysis, and two U.S. participants were eliminated because they did not rely on their calculations to make their final decision. This resulted in a final sample of 193 participants, 89 in the U.S. and 104 in Mexico. Table 1 presents the demographic characteristics of the participants. The results of chi-squared tests revealed that there were no significant differences among cells in either gender or educational level of participants. In addition, one-way ANOVA tests were performed to test for differences in questionnaire results, work experience, and time spent answering the experimental instrument. No significant differences were found.

Table 1

Demographic Characteristics ( $\mathrm{N}=193)$

\begin{tabular}{|c|c|c|c|}
\hline Characteristics & Number (N=89) & Number (N=104) & Percentage (\%) \\
\hline Gender & United States & & \\
\hline Male & & 59 & 57.5 \\
\hline Female & 52 & 45 & 42.5 \\
\hline Academic classification & 37 & & \\
\hline Graduate & 41 & 50 & 47.2 \\
\hline Undergraduate & 48 & 54 & 52.8 \\
\hline
\end{tabular}

Table 2

Hypotheses Testing (H1) Frequency Table And Chi-Squared Test Of Accounting Measure Used By Country

\begin{tabular}{|c|c|c|c|c|c|}
\hline & & & \multicolumn{2}{|c|}{ Measure used } & \multirow[t]{2}{*}{ Total } \\
\hline & & & Earnings & Cash Flow & \\
\hline \multirow{5}{*}{ Country } & \multirow{3}{*}{ United States } & Count & 66 & 23 & 89 \\
\hline & & Percent & $74.2 \%$ & $25.8 \%$ & $100.0 \%$ \\
\hline & & Row percent & $63.5 \%$ & $25.8 \%$ & $46.1 \%$ \\
\hline & \multirow[b]{2}{*}{ Mexico } & Count & 38 & 66 & 104 \\
\hline & & Percent & $36.5 \%$ & $63.5 \%$ & $100.0 \%$ \\
\hline \multirow{3}{*}{\multicolumn{2}{|c|}{ Total }} & Count & 104 & 89 & 193 \\
\hline & & Percent & $53.9 \%$ & $46.1 \%$ & $100.0 \%$ \\
\hline & & Row percent & $100.0 \%$ & $100.0 \%$ & $100.0 \%$ \\
\hline
\end{tabular}

$\chi^{2}=27.313$

$p<0.001$ 
As expected, the majority of U.S. participants relied on earnings in their analysis (74.2\%), while the majority of participants in Mexico used cash flows (63.5\%). Table 2 reflects these frequencies. A chi-square test provides evidence that there is a significant difference in whether earnings or cash flows are used more on average by participants in the two countries.

The responses from participants in both countries who relied on earnings in their analysis were examined further. Panels A and B of table 3 reveals that participants in both countries who used earnings in their analyses arrived at the incorrect decision most of the time In the U.S., $83.3 \%$ of participants relying on earnings made the incorrect decision compared to $84.2 \%$ for the Mexican participants. Performance was better in both companies when participants relied on cash flow information, with only $21.7 \%$ of those U.S. participants making the incorrect decision compared to $19.7 \%$ for the Mexican participants.

Table 3

Frequency Table Of Correct And Incorrect Answers To The Instrument By Measure Used Panel A. United States Subjects

\begin{tabular}{|c|c|c|c|c|c|}
\hline & & & \multicolumn{2}{|c|}{ Decision } & \multirow[t]{2}{*}{ Total } \\
\hline & & & Incorrect & Correct & \\
\hline \multirow{6}{*}{ Measure used } & \multirow{3}{*}{ Earnings } & Count & 55 & 11 & 30 \\
\hline & & Percent & $83.3 \%$ & $16.7 \%$ & $100.0 \%$ \\
\hline & & Row percent & $91.7 \%$ & $37.9 \%$ & $63.8 \%$ \\
\hline & \multirow{3}{*}{ Cash Flow } & Count & 5 & 18 & 17 \\
\hline & & Percent & $21.7 \%$ & $78.3 \%$ & $100.0 \%$ \\
\hline & & Row percent & $8.3 \%$ & $62.1 \%$ & $36.2 \%$ \\
\hline \multirow{3}{*}{\multicolumn{2}{|c|}{ Total }} & Count & 60 & 29 & 47 \\
\hline & & Percent & $67.4 \%$ & $32.6 \%$ & $100.0 \%$ \\
\hline & & Row percent & $100.0 \%$ & $100.0 \%$ & $100.0 \%$ \\
\hline
\end{tabular}

Panel B. Mexico Subjects

\begin{tabular}{|c|c|c|c|c|c|}
\hline & & & \multicolumn{2}{|c|}{ Decision } & \multirow[t]{2}{*}{ Total } \\
\hline & & & Incorrect & Correct & \\
\hline \multirow{6}{*}{ Measure used } & \multirow{3}{*}{ Earnings } & Count & 32 & 6 & 30 \\
\hline & & Percent & $84.2 \%$ & $15.8 \%$ & $100.0 \%$ \\
\hline & & Row percent & $71.1 \%$ & $10.2 \%$ & $63.8 \%$ \\
\hline & \multirow{3}{*}{ Cash Flow } & Count & 13 & 53 & 17 \\
\hline & & Percent & $19.7 \%$ & $80.3 \%$ & $100.0 \%$ \\
\hline & & Row percent & $28.9 \%$ & $89.8 \%$ & $36.2 \%$ \\
\hline \multirow{3}{*}{\multicolumn{2}{|c|}{ Total }} & Count & 45 & 59 & 47 \\
\hline & & Percent & $43.3 \%$ & $56.7 \%$ & $100.0 \%$ \\
\hline & & Row percent & $100.0 \%$ & $100.0 \%$ & $100.0 \%$ \\
\hline
\end{tabular}

Further analysis of the participants' calculations suggests that they arrived at the wrong answer when using earnings because they failed to adjust earnings for depreciation. Because depreciation is a non-cash expense, they should have added depreciation to earnings when projecting future cash flows. 


\section{SUMMARY AND CONCLUSIONS}

This study examined whether students understand the accrual process in dealing with depreciation by testing if they would properly adjust accrual income for depreciation when making decisions requiring cash flow projections. We predicted that students in Mexico would be able to better make this adjustment since cash flow is seen as a more important measure than accrual income in Mexico. The evidence provided by our study indicates that neither students in the U.S. or Mexico understand the role of depreciation in accrual income versus cash flows.

The results of this study should be of interest to academicians in both the U.S. and Mexico, as well as globally. Students in both of these universities had been exposed to accounting for depreciation through coursework using a traditional accounting textbook and approach. This study highlights the need for new methods of approaching this topic in the classroom to be developed, experimented with, and introduced. We, as educators, need to assure that our teaching methods and techniques are effective in helping students reach a thorough understanding of the material.

As with all experimental studies, there are limitations as to the generalizability of the results of this study to other settings.

\section{REFERENCES}

1. Bartov, E., S.R. Goldberg, and M.S. Kim. 2001. The valuation-relevance of earnings and cash flows: an international perspective. Journal of International Financial Management and Accounting 12(2): 103-132.

2. Beaver, W. and R. Dukes. 1972. Interperiod tax allocation, earnings expectations, and the behavior of security prices. The Accounting Review 47: 624-652.

3. Biddle, G., R. Bowen, and J. Wallace. 1997. Does EVA beat earnings? Evidence on associations with returns and firm values. Journal of Accounting and Economics 24: 301-336.

4. Bowen, R., D. Burgstahler, and L. Daley. 1986. Evidence on the relationship between earnings and various measures of cash flow. The Accounting Review 61: 713-725.

5. Bowen, R., D. Burgstahler, and L. Daley, 1987. 1987. The incremental information content of accrual versus cash flows. The Accounting Review 62: 723-74.

6. Dechow, P. 1994. Accounting earnings and cash flows as measures of firm performance: the role of accounting accruals. Journal of Accounting and Economics 18: 3-42.

7. Hung, M. 2001. Accounting standards and value relevance of financial statements: an international analysis. Journal of accounting and economics 30: 401-420.

8. Moehrle, S., J. Reynolds-Moehrle, and J. Wallace. 2001. How informative are earnings numbers that exclude goodwill amortization? Accounting Horizons (September): 243-255.

9. Swanson, E., L. Rees, and L. Juarez-Valdes. 2003. The contribution of fundamental analysis after a currency devaluation. The Accounting Review 78(3): 875-902. 


\section{NOTES}

